\title{
FRONTLINE
}

\section{Place-makers of the mind Symbolic reconstruction of an inner city park}

\begin{abstract}
In 2016, a specialist unit that teaches university journalism students how to report in partnership with Indigenous community organisations extended its story range to a news feature produced with members of the wider Nyoongar community of Perth, Western Australia. The story asked the question of what happened to a stalled proposal to co-badge a major inner city park with a Nyoongar name. In conceiving the story and producing it with assistance from our students, we achieved clarity on a local government decision where due process had not been followed. With the help of Nyoongar sources, our team sought to explain the cultural importance of the park and raise awareness of the decolonising potential of Indigenous place names. We and our students advanced discussion of the park's name, mediating between the broader public, Nyoongar people and a council administration to produce journalism that influenced a political process by privileging Indigenous voices. The following exegesis melds sense of place theory with the field theory of Pierre Bourdieu to situate the story and its producers in social space.
\end{abstract}

Keywords: Bourdieu and journalism, Indigenous, Indigenous affairs journalism, Indigenous place names, journalism education, journalism and place, Noongar voice, Nyoongar voice

\section{CHRIS THOMSON and BONITA MASON \\ Curtin University, Wadjuk Nyoongar country, Perth}

\section{Introduction}

-HIS RESEARCH article combines sense of place theory and the field theory of Pierre Bourdieu to contextualise a news feature story conceived by us, and produced with the assistance of university students who were undertaking a specialist Indigenous affairs journalism unit, founded in 2013, called Aboriginal Community Engagement (ACE).

The paper is presented in two parts, an exegesis on the story, then the story itself titled 'Aboriginal park name revived'. The story re-elevated to public attention a lapsed debate over a plan to co-badge an inner city park with a name reflecting its importance to the Wadjuk Nyoongar people who have occupied what is now metropolitan Perth for at least 38,000 years (Pearce \& Barbetti, 1981). 
We and the students increased the visibility and transparency of a local council decision-making process, thereby performing a core role of journalism-to keep governments accountable. Our intention was to provide a platform for the oft-marginalised Wadjuk Nyoongar voice to be privileged and heard in debate over the park's name. ${ }^{1}$ Working with Nyoongar people as story subjects and sources, we contested abbreviated and dominant collective memories (Zelizer, 1995, p. 214) - and some racist depictions - of the park. We were thus able to provide historical context that captured the park's under-recognised importance to Nyoongars from ancient to modern times. By reflecting here upon how we did that, we seek to make overt what journalists have long kept covert- their centrality in the production of collective memory (Zelizer, 2008, p. 79).

The exegesis commences with background about the topic of the story-a park called Weld Square, and a stalled plan to co-badge it with an Aboriginal name. We then briefly describe the ACE unit, which is outlined in more detail at Thomson, et al. (2016). To explain why we became interested in the topic of the story, we review literature that attests to the socio-political importance, and decolonising ${ }^{2}$ potential, of place names, with an emphasis on the 242,000 sq km south-western corner of Australia where more than half of all place names are of Nyoongar origin. Finally, to situate the story and its producers in social space, we draw on work presented in Thomson, et al. (2015) that links sense of place theory to Bourdieusian field theory.

\section{Part 1: The exegesis \\ Background}

Because Nyoongar country was the first in Western Australia to be colonised, 'with significant lags to colonisation elsewhere in the state', Nyoongar people 'bore the brunt of colonisation' (Thomson, et al., 2016, p. 62). The Nyoongar community was 'enormously affected by white settlement ..., forced off their land and dispersed to other areas' (Bennell v Western Australia, 2006). However, as the South West Aboriginal Land and Sea Council and others note, 'despite [now] being in a heavily urbanised area, Noongar people continue to practise traditional ways’ (2009, p.xiii).

Located in the suburb of Perth, the epicentre of early Western Australian colonisation, Weld Square was named after the state's eighth governor, Frederick Weld. The park is a state-listed Aboriginal heritage site significant to Wadjuk Nyoongar people who had gathered there since long before the late 1800s when Governor Weld ordered that the place be transformed from a wetland into an Arcadian-style reserve. After becoming a park, Weld Square 'was used as a camping ground and meeting place and continues to have great importance for Aboriginal people' (City of Vincent, p. 1). In an article that won the Australian Institute of Landscape Architects' inaugural essay prize, Sawyer writes: 
Weld Square is a curious place, physically shaped by its colonial heritage yet spiritually defined by its black presence. Aborigines had established a strong connection to the site prior to white settlement. As one local commented, 'Noongar been living here since God was born, probably.' (Sawyer, 1998)

In the 20th century, the area around Weld Square, which sits immediately outside the municipal boundary of the City of Perth (Western Australia's capital city), gained renewed significance as a meeting place for Aboriginal people who, from 1927 until 1954, were prohibited from entering the capital city after 6pm (South West Aboriginal Land and Sea Council, n.d.). The prohibition stood even if an Aboriginal person held a native pass, a passport-like document that permitted daytime access only for Aboriginal people who had 'legitimate reason' to be in the so-called 'Prohibited Area'. From 1946 to 1960 the Aboriginal-run Coolbaroo League Dance Club was located across the street from Weld Square. The club was one of the few places in greater Perth where Aboriginal people and people of European descent could socialise, and vice versa. 'Coolbaroo' is a word of the Yamatji people of the Gascoyne and Murchison areas of Western Australia that means 'magpie', whose black and white plumage symbolised the club's multicultural ethos. Haebich (University of Western Australia, 2014) observes that:

In creating the Coolbaroo dances, the League drew on the community's love of dancing and singing together dating from time immemorial and the capacity of dance and song to affirm their cultural and spiritual identities and bring strength to negotiate the political complexities of the new policy of assimilation. (University of Western Australia, 2014)

As Nyoongar elder Albert Corunna told us for the following story:

When we came to dance right on the edge of the Prohibited Area, we made a political statement as well as having a good time.

The club hosted both Nyoongar and visiting entertainers including the worldfamous Harlem Globetrotters and Nat King Cole (creativespirits.info, n.d.). After the club wound up, its leaders formed the Aboriginal Advancement Council, which 'remained a voice for social change' (creativespirits.info, n.d.). The council was also located near Weld Square.

Thomson (2011) was the first journalist to report that a plan to co-badge Weld Square with an Aboriginal name had been floated by officials at the City of Vincent, the municipality beside the City of Perth in which Weld Square is located. After a follow-up story (Thomson, 2012), he monitored council papers for any developments. There were few-until the agenda of the 2016 City of 
Vincent annual general meeting revealed that former city councillor Dudley Maier had asked that the plan be reactivated. Maier's notice of motion in the agenda papers placed on the public record that the plan had never been referred to an advisory group, as agreed at a council meeting when he was a city councillor, and hence had not progressed according to due process.

\section{Aboriginal Community Engagement unit}

Maier's action provided impetus for teachers and students of the Aboriginal Community Engagement (ACE) unit to investigate why the plan had fallen off the public agenda. One aim was to keep the City of Vincent accountable on this potentially decolonising proposal. Another was to ensure that Nyoongar and other people were aware of - and had the opportunity to add their voice todebate over the park's name. To this end, our students visited Weld Square several times to interview Nyoongar and other park-goers. The students also conducted interviews with two Nyoongar presenters at Noongar Radio (a partner organisation of the ACE programme), which is located across the street from Weld Square. Thomson located and conducted telephone interviews with two Nyoongar Elders authorised by custom to speak about the park: academic Ted Wilkes, and a more senior Elder, or as Associate Professor Wilkes called him, a birdiya, or 'boss', Elder, his uncle Albert Corunna. This approach to sourcing interviewees and informants is important in ACE, where we consciously seek out non-official (Ericson, et al., 1989) and otherwise marginalised sources: Hall, et al's (1978) counter-definers, who are routinely-often through omission-denied access to the media, only gaining access when they disrupt the 'social order' and/or speak and act in the terms set by that social order.

The story built on skills taught in ACE, which partners students with Nyoongar community organisations to tell journalistic stories that the organisations are willing to share. Through ACE, students are introduced to the action research cycle of look, think and act (Johnston, et al., 2015a) that shares much with the observe, listen and research; reflect, interpret and analyse; and report and publish aspects of reflexive journalistic practice. They receive tuition on the critical reflexivity of Bourdieu and reflective practice of Donald Schön that enables them to conceptualise their position in the journalistic field, and structure their reflections on practice. They learn about sense of place, particularly the concept of contested place and the under-recognised importance of the 'where' question in journalistic investigation in the era of the world wide web (Thomson, et al., 2015). Students also hear from Nyoongar lecturers with backgrounds in the field of cultural production. A field trip led by Curtin University's Elder-in-Residence, Simon Forrest, retraces the route of a punitive raid led by the state's first governor in 1834 that killed an estimated 14 to 30 Nyoongar people at Pinjarra, south of Perth (Stasiuk, 2015, pp. 77-79). The attack was a watershed moment 
in the shared history of Aboriginal people and Western Australians of European descent (Forrest, 2014).

In ACE, the orthodox 'journalism teaching technique of simulating a deadline-driven newsroom, in which students are required to extract stories from sources in a compressed timeframe' is deliberately inverted (Thomson, et al., 2015, p. 149). The emphasis is on student collaboration with Indigenous community organisations first, and on story production second. For the Weld Square story, the collaboration was extended beyond individual community groups to representatives of the wider Wadjuk Nyoongar community. Staff and students worked over several weeks on a story that allowed Wadjuk Nyoongar people to share information in a timeframe with which they were comfortable. The story was published on 20 June 2016 on both the Curtin University news website https://inkwirenews.com.au and a new ACE website http://communityyarns.com.

ACE provided the theoretical framework for students to practise critically reflexive Indigenous affairs journalism on a story designed to influence public debate. In 2016, the 25th year since the Royal Commission into Aboriginal Deaths in Custody recommended (1991a, Recommendation 207b) that Australian universities establish units of study dedicated to Aboriginal affairs reporting, it is timely to note that $\mathrm{ACE}$ and another Curtin University unit, Noongar Dandjoo (Johnston \& Bishop, 2013), were the only two such units taught in Australia to be documented in academic literature. Both units encourage students to take on perspectives of Indigenous people, consistent with the intent of the Royal Commission, which noted that 'the voice of Aboriginal people is often markedly absent' from large-scale media publications (Royal Commission, 1991b, 12.6.6).

\section{Discussion}

Staff and students conducted desktop research on the history of Weld Square, which clarified how important the park is to Nyoongar people. One student tasked with sourcing the City of Vincent's side of the story was told, after several requests, that the council was too busy to respond. Thomson intervened by emailing the media liaison officer with whom the student had been dealing, and copying in the mayor. The city CEO belatedly commented, providing a frank admission that the plan should have been referred to the above-mentioned advisory group and assuring us that it would now be referred to the city's new Reconciliation Action Plan Working Group. The CEO added information about an upcoming celebration of Aboriginal culture at Weld Square.

In Western Australia it is becoming harder for journalism students to elicit responses from public officials because, increasingly, journalists' questions must be submitted via email to media relations staff. As they are often unsure if their work will be published and are not yet expert at asking questions, students are less likely than professional journalists to be taken seriously. Structurally, as new 
entrants (Bourdieu, 1996/1992, p. 243) to the field, journalism students occupy a relatively dominated position-akin to Hall, et al's (1978) counter-definers in the power relations expressed through the journalist-source relationship. A field strategy we teach them is to interview well beyond official sources, both to include a greater diversity of voices and so they are not reliant on official sources getting back to them. We have found that when students and journalism educators work together on stories, the likelihood of student questions being taken seriously increases. By eventually agreeing to participate in the story, the city gained an opportunity to explain its position and promote its efforts at Weld Square to advance reconciliation between Perth's Aboriginal and non-Aboriginal people. The city's response also validated the importance of place names whose impact on the perpetuation or amelioration of colonialism often eludes public consciousness but whose analysis through the academic discipline of critical toponym studies is an established area of research, including in the Pacific (e.g. Herman (1999) in Hawai'i and Berg \& Kearns (1996) in New Zealand).

Just as colonial symbolism embedded in flags that carry a Union Jack has been the subject of periodic debate across Australia (Foley, 1996) and recent debate (e.g. www.nz.com, n.d.) leading to a national referendum in New Zealand, we argue that colonial obliteration of Indigenous symbols in the form of place names merits greater consideration by journalists. As Cohen and Kliot (1992, p. 653) state, 'names are symbolic elements of landscape that reflect abstract or concrete national and local sentiments and goals'. In thinking about this, we draw on the work of Bourdieu who observes that in post-industrial societies symbolic manipulation is more powerful in reproducing social inequality than the threat of physical violence (Swartz, p. 82). Bourdieu's formative fieldwork in the 1960 s with the Indigenous Kabyle people of Algeria and parallel consideration of colonialism were foundational in the development of his later concepts including 'habitus, field, and reflexive sociology' (Go, 2013, p. 51). He coined the term 'symbolic violence' to describe invisible and hence misrecognised (Calhoun \& Wacquant, 2002, p. 1) inegalitarian power relations - particularly misrecognised by people and groups dominated by those relations. It is the misrecognition of symbolic violence that imbues it with power by 'induc[ing] the dominated to accept their exclusion as legitimate' (Wacquant, p. 28). Bourdieu's stated charter, to 'reveal that which is hidden' (Bourdieu, 2001, p. 246) with the goal of defusing the inegalitarian effects of misrecognition, accords with the ethos of social justice journalism taught in ACE.

The names of places have significant and enduring, if unrecognised and misrecognised, symbolic power to either reinforce social domination by cultural elites, or to assist the struggle of culturally dominated peoples to liberate themselves through movements including decolonisation and reconciliation. As Saparov wrote: 
Place-names are some of the most durable of national symbols. They can outlive most material artefacts of a civilisation. The material components of the cultural landscape may disappear or be destroyed, the civilisation that created them may also disappear but its place-names will most probably survive. ( Saparov, 2003, p. 179)

In one international example, when making way for the former Soviet Union, the Bolsheviks 'destroyed the churches, monuments, institutions and placenames of the Tsarist regime' and 'undertook unprecedented place-name changing campaigns managing to replace up to half of all place-names in the USSR' (Saparov, 2003, pp. 180-181). In many of these places, the original names have been restored.

Saparov's 'up to half' estimation has inverse resonance in south-western Australia where 'more than 50 percent' of place names have their origin in the Nyoongar language (Collard, et al., 2011, p. 1). This is the largest proportion of preserved Indigenous place names of any Australian region (p. 1). Although relations between colonisers and Indigenous Australians have been vexed, University of Western Australia academic Leonard Collard (2011), a Nyoongar man, and his colleagues, observe that Nyoongar place names were preserved by the kind of cross-cultural collaboration that could inform and enrich the future of Australia (p. 7). In an interview with an ACE student (Leggett, 2015), Professor Collard explained the importance of Nyoongar place names allegorically, in terms of resistance to colonial dispossession and why, despite the substantial number of surviving Nyoongar place names, this form of redress remains important in Nyoongar country:

When I was at school, my mum would say to me: 'Son, write your name on your school property'; i.e. my school bag, or my hat. And I would say to her, 'Mum, why would I do that? I know my name'.

She would say, 'You might ... but others might not'.

And so, today, of course, we know that this is Noongar land - because it has our name on it. (Leggett, 2015)

Rapoport (1972, p. 338), an architecture academic, noted that Indigenous Australians do not 'move just in a landscape but in a humanised realm saturated with significations' and put great importance on the naming of places. Plumwood (2005) sees the return to Indigenous place names in some parts of Australia - which has included such national landmarks as Ayers Rock (Uluru), the Olgas (Kata Tjuta) and the Hamersley Ranges (Karijini) - as a form of 'deep republicanism' that respects 'the uniqueness and power of place as well as recognising its prior naming and occupation by Aboriginal people' (p. 386). She sees the restoration of Indigenous place names as a symbolic step toward 
decolonisation. Consistent with this is Cohen and Kliot's observation that:

In the twentieth century, colonialism, communism, decolonisation, and now the rejection of communism, have all been attended by widespread changes in place-names. (Cohen \& Kliot,1992, p. 653)

Place names, of course, are a subset of all names, which Bourdieu (1989) says are 'the categories of perception, the schemata of classification, ... the words ... which construct social reality as much as they express it' (pp. 20-21). He continues:

In the symbolic struggle for the production of common sense or, more precisely, for the monopoly over legitimate naming, agents put into action the symbolic capital that they have acquired in previous struggles and which may be juridically guaranteed. (Bourdieu, 1989, p. 21)

He adds that the ability to control the production of common sense by monopolising the power to name is the power to make the world (p. 22). Through this Bourdieusian lens it can be seen that our story deployed the symbolic power of journalism for egalitarian purposes to help break the monopoly, juridically held by local and state governments, over the naming of places. While progress toward democratising the name of Weld Square had been made half a decade ago, that process had ground to a halt. Our story revealed controversy over the imposition of 'just any' Aboriginal place name. With the help of Nyoongar sources, we and the students demonstrated that simplistically seizing on a place name had potential to perpetuate colonialism by serving, symbolically, to further displace Wadjuk Nyoongar people from inner Perth.

An example of attempted monopolisation of 'common sense' by members of an economically dominant sector of Perth society_its property development industry - can be seen in comments left unchallenged on an online chat forum (skyscrapercity.com, 2012) in relation to the posting of an earlier article by Thomson (2012) about the name of Weld Square:

That Wongi Park idea is stupid. When I lived around the corner, the park was always full of drunk aboriginals. They were never 'chatting' or 'meeting'- just drinking and fighting, and occasionally begging for money. It's like the council wants to enshrine that behaviour and make it part of the park's 'culture'. What a load of shite.- 'city thing'

Isn't that recognising its heritage? $\because$ _ 'wexford'

Give dual names to things that existed before European settlement. Allocating Aboriginal names to parks like this is just pathetic. - 'PerthCity' Goonbag Park. —'Ari Gold' 
In Australian slang, a goon bag is the plastic bladder from a cask of cheap wine. 'Ari Gold' is implying that Aboriginal people only gather at Weld Square to drink cheap alcohol. Relevant here is Spencer's (2005) observation that: 'the effects of drinking on Indigenous culture have clearly been used by white Australians to affirm their place on higher moral ground, and as a means of racist ridicule and paternalism ...' (pp. 182-183).

By presenting a fuller and fairer picture of the park's heritage, our story confronted racist perceptions posted on skyscrapercity.com. By visiting the park and interviewing Nyoongar people who were there, our students debunked both the implication of 'Ari Gold' and the statement by 'city thing'. By offering a counter-view that explained Nyoongar people's profound connection to the park, we and the students contested the dominant and abbreviated collective memory (Zelizer, 1995, p. 214) of Weld Square as jaded Arcadian reserve and challenged the commenters' ability to monopolise people's perception of place. At a time when the term 'place-making' has crossed over from sociology and architecture and other spatial design fields, where it originally was concerned with community building, into a brand, thanks to its usurpation by the property industry (Project for public places, n.d.) to sell real estate, we and the students sought to disrupt the hegemonic construction of the park in the minds of Perth's people. We engaged in a symbolic form of place-making closer to the original spirit of the term.

Despite the skyscrapercity.com comments, and a lingering propensity for the current Western Australian government to name prominent places after members of the British royal family (Holmes \& Thomson, 2012), several recently reshaped places have officially been given Nyoongar names. One example is Yagan Square, named after a Nyoongar freedom fighter at the time of colonisation, at the government's emerging \$A5.3 billion Perth City Link project. Another is Perth's newest beach, at a marina development in the city's southern suburbs, which has been named 'Ngarkal Beach' after the Nyoongar name for 'seagull' (Thomson, 2014). By re-illuminating the plan to confer an Aboriginal name on an existing place in a city of two million people (as opposed to remote national parks such as Uluru, Kata Tjuta or Karijini) our pedagogical approach aimed to counter 'the notion held by many non-Indigenous Australians that real Aborigines live in the bush, and that Aboriginal people who live in urban areas have lost their culture' (Johnston, et al., 2015b, p. 196). We plan to follow up the Weld Square story with future students, and have several other place-based story ideas we would like to produce in collaboration with Nyoongar people.

In a globalised era when the 'where?' question in the 'what, where, who, why, how and when?' template of journalistic investigation is increasingly disregarded (see, for example, Buchanan, 2009; Funk, 2012), collaborating with Indigenous sources can reverse this by informing journalists about the underlying character 
of places. From Bourdieu, who connects his theoretical mainstay of habitus (see Mason, et al., 2016) with the notion of place, stating that habitus 'implies a "sense of one's place" and a "sense of the place of others" (Bourdieu, 1989, p. 19) within a field of endeavour, Thomson, et al. (2015, p. 141) suggest two potential benefits. One is that working with Indigenous people can help students imagine the type of journalist they want to be; the other is a more secure sense of place in the media for Indigenous people. This latter point is pertinent in Perth where there is a generally poor standard of Indigenous affairs journalism punctuated by misrepresentation and selective negative reporting (Thomson, et al., 2016, p. 46), which can be theorised in Bourdieusian terms as:

the absence of homology between a highly dominated group of people in the field of social classes and the city's powerful subfield of large-scale journalism influenced by heteronomous economic forces that instead stimulate homologous correspondence with the top end of town. (Thomson, et al, 2016, pp. 48-49)

By contrast, Thomson, et al. (2016, p.49) observe that 'student journalists, who usually occupy the dominated subfield of small-scale journalism, have great potential to form relationships' with Indigenous sources to address the exclusion and negative media portrayals of Nyoongar people. In Bourdieu's (1993) words, 'the initiative of change falls almost by definition on the newcomers, i.e. the youngest, who are also those least endowed with specific capital' (p. 58).

In the footsteps of journalism educators elsewhere in Australia and the Pacific who have encouraged students to engage with Indigenous communities (Thomson, et al., 2015, p. 146), our team worked with Nyoongar people to produce a story on a topic of metropolitan significance that large-scale metropolitan news producers had declined to cover, but which a small-scale metropolitan news website (Thomson, 2011, 2012) and a locally owned suburban newspaper (Bell, 2012, 2013) did cover. As Bacon (2006) notes: 'The point of being in a university is to be able to question, not to replicate conventional practice' (p. 148). Through questioning conventional practice, we and the students engaged in the type of struggle that defines the structure of fields - that between large-scale producers which tend to dominate due to their access to large reserves of economic capital and small-scale producers instead more likely to possess more cultural capital than economic capital (Bourdieu, 1996, p. 124). The specific field struggle we entered was one between the news values of Perth's large-scale news producers that tend to valorise the holders of economic capital (Thomson, et al., 2016, pp. 48-49), and news values of the two abovementioned small-scale publishers that privileged the concerns of a people who have at least 38,000 years of cultural capital. 
As small-scale journalistic producers whose news values were closer to the latter set of values, we-like Mason (2014, p. 167) as a freelancer when writing an Indigenous affairs story that won national journalism awards - were 'unconstrained by the routines and structures of mainstream news production, including deadlines, story competition, editorial preferences and privileging official sources'. This helped us form relationships and 'take the time required for trust to develop ... [which] was given precedence over deadlines and other more orthodox journalistic considerations' (Mason, 2014, p. 161). Just as the most culturally attuned architects engage deeply with people and local conditions as accomplished place-makers in the physical world, we conclude that deep engagement with Indigenous people on place-based stories can empower journalism academics, practitioners and students to become proficient placemakers of the mind.

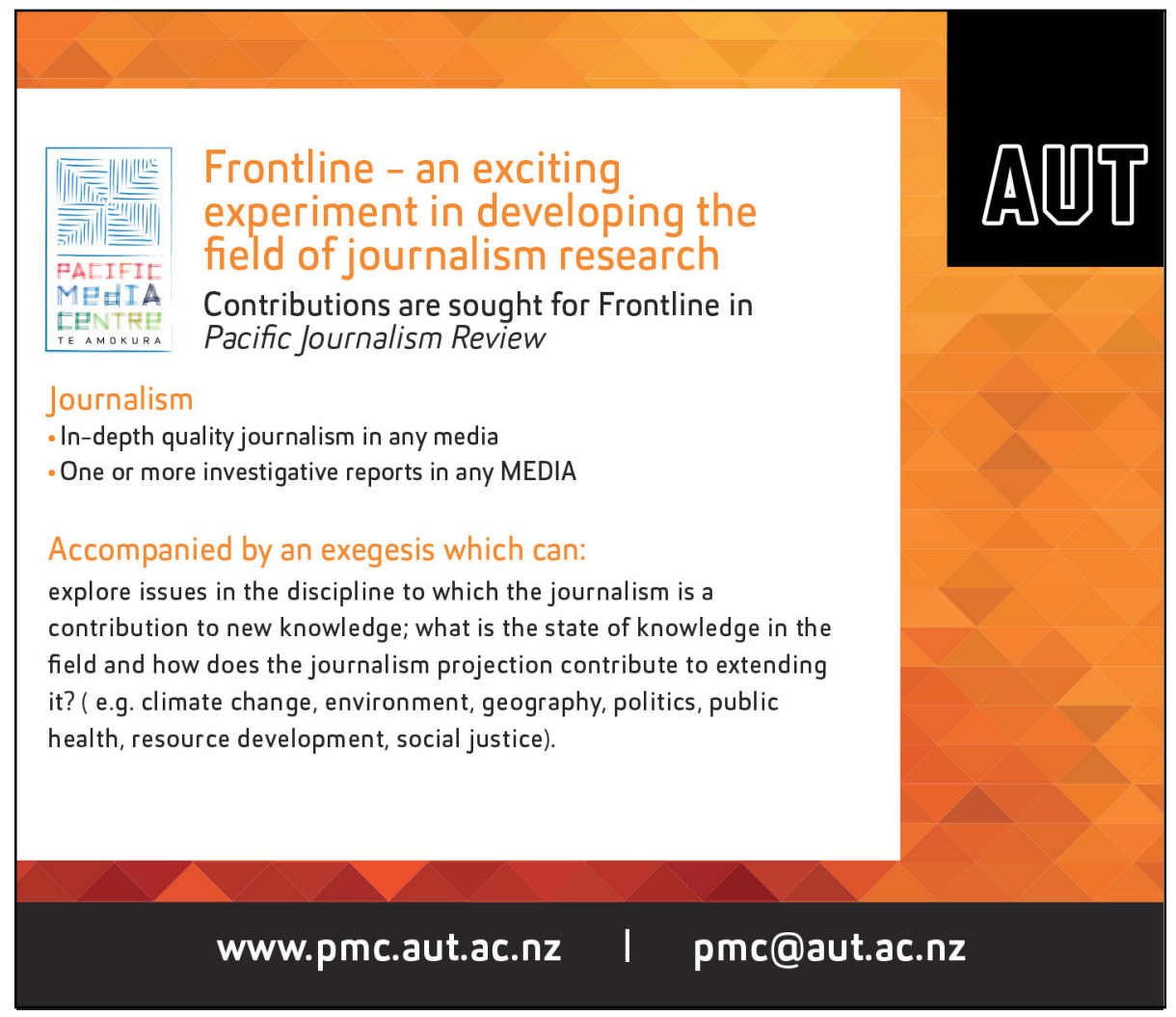




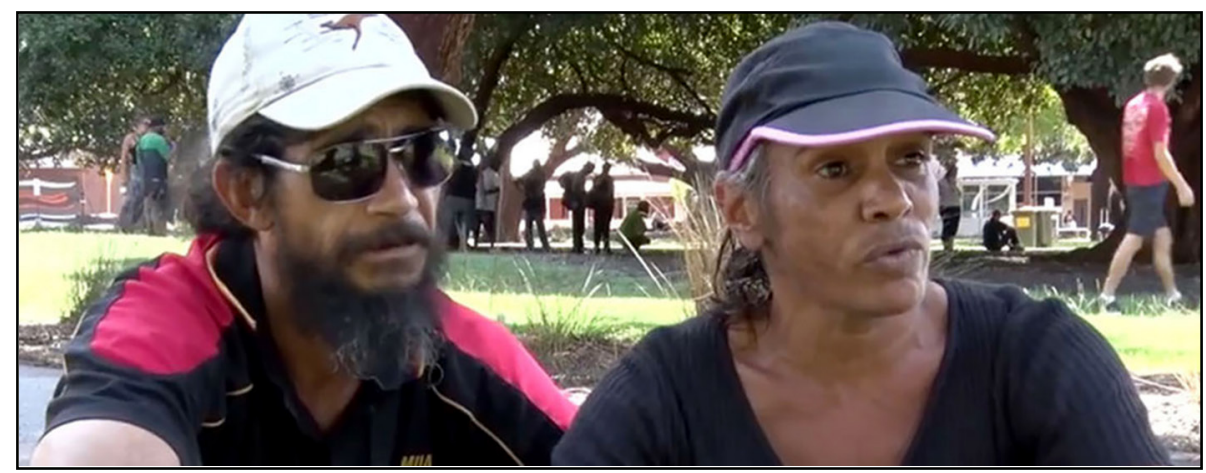

Leeandrew Holden and Pamela Morrison down at Weld Square.

\section{Part 2: The story}

This was originally published with a video, hyperlinks, pull-quote and an opinion poll at https://inkwirenews.com.au/2016/06/20/noongar-park-name-back-on-theagenda/:

\section{Aboriginal park name revived}

ALASDAIR BEER, JACOB HIGGINS, REBECCA KERR, GENEVIEVE LAMOND, BONITA MASON, SAFIAH RIND, TELISSA RYDER, LAURA THOMAS and CHRIS THOMSON

\footnotetext{
A stalled plan to co-badge a major Perth park with a name that recognises its Aboriginal heritage has been officially jump-started, with a new council committee set to consider it next month.

Weld Square is an 11,500 sqm reserve bounded by Beaufort Street, Newcastle Street, Stirling Street and Parry Street in inner-Perth.

The park is overlooked by the urbane Ellington Jazz Club, and a phalanx of high-priced apartments in what, until a decade or so ago, was an unfashionable part of town.

Weld Square and its surrounds have never been unfashionable with Perth's Nyoongar people, however.
}

\section{COOLBAROO CLUB}

The reserve was once part of a wetland that drained into the Swan River, and has been a Nyoongar meeting place for thousands of years.

In the 1950s, the then Braille Hall, at the corner of Newcastle and Stirling streets, hosted Aboriginal-run Coolbaroo League Dance Club dances. The group behind the club, the Coolbaroo League, lobbied the State government of the day to rescind the Prohibited Areas Policy that from 1927 to 1954 banned all Aboriginal people from the City of Perth unless they had a work permit, and those with a permit from being in the Western Australian capital after 6pm. 
Fast forward to 2016 and, at the City of Vincent's Annual General Meeting, former city councillor Dudley Maier moved that a dormant plan to co-badge the park with a Nyoongar name acceptable to Perth's Aboriginal community be reactivated.

Ahead of the meeting, Maier advised that the plan had never been referred to the community-led Aboriginal Liaison and Reconciliation Advisory Group as required by a council decision of July 12, 2012.

Council CEO Len Kosova has confirmed the plan was not referred to the advisory group.

"This should have occurred and there is no clear evidence available to ascertain why it did not happen," Kosova said.

"It should be noted that the Aboriginal Liaison and Reconciliation Advisory Group is a community-driven group operating in the City of Vincent which the city has actively engaged with from time to time.

"However, that group is not a formal City of Vincent advisory group established by council."

On May 31 the city appointed a new Reconciliation Action Plan Working Group. Kosova said the group would meet for the first time in July, subject to availability of its members. He said the plan to co-name the park would be considered at that meeting.

"It is likely that the Working Group will deal with this matter through a specific action within the [council's] Reconciliation Action Plan," Kosova said.

\section{OUSTED}

Maier said that after he was voted out in 2013, a plan to co-badge the reserve as Weld Square/Wongi Park went nowhere, probably due to lack of interest among the council and the Vincent community generally.

He said the recommendation to refer the matter to the advisory group never eventuated, as the group never met.

"It was established, and I was notionally on it, but the group actually never met," Maier said.

"Had the group had a scheduled meeting it might have been added to the agenda.

"And the name 'Wongi' - a few people in Vincent thought it wasn't such a great name.

"I think maybe they were expecting a traditional name for the area, and there may not have been a traditional name."

Mechelle Wilson, a presenter and producer at Noongar Radio, which sits across Beaufort Street from Weld Square, opposes any notion that the park be named 'Wongi', due to a lack of relevance to Nyoongar people.

"I know this because my grandfather is from Nyoongar country and my grandmother is from Yamatji country where 'Wongi' means 'talk', definitely," Wilson said.

"You're using an Aboriginal name that has no relevance to this area whatsoever or the people-so if you'd [have] done that there would be a huge misun- 
derstanding and it would also be great disrespect to use another First Nation's language which also relates to another group of First Nation people.

"Wongi means 'talk' in Yamatji country which is Midwest area Aboriginal people, so there is no link towards this First Nation area here of Nyoongar people, and the word that we use on Nyoongar country for talk is 'Wangkiny' which is 'talk' and 'Wangkininy' which means talking.

"To look at the word 'Wongi', it also means 'Wongi', pronounced with a hard 'i', which are the Aboriginal people from The Goldfields like Kalgoorlie and that, so l'd say you got the wrong name and there's no connection with that name to this area.

"It doesn't belong."

The council's original idea to co-name the reserve 'Wongi Park' was meant to reflect the fact that Nyoongar people had met 'to talk' at the reserve for generations.

Another presenter and producer at Noongar Radio, Jodi Ryder, also a Nyoongar woman, said that giving the park a Nyoongar name would "be more inclusive for Aboriginal people".

\section{GOVERNOR WELD}

Named in 1873 after Western Australia's eighth governor, Frederick Weld, a New Zealander, Weld Square is a state-listed Aboriginal heritage site. Governor Weld engaged town planner William Ernest Bold and architect Harold Boas to design the park, which was not landscaped until 1898.

Maier said his favoured approach to recognising the park's Nyoongar heritage was for a sign to acknowledge its significance, without necessarily changing the name.

He said that while the city's Hyde and Robertson Parks have Nyoongar names discernible from colonial-era maps, no-one seemed able to provide an actual Nyoongar name for Weld Square.

"I suppose the idea we had was that Weld Square could be the first [in the city where Nyoongar heritage was recognised], and then you could have Hyde Park and Robertson Park, and things like that, where you could put some recognition, because Hyde Park and Robertson Park do have recognised Aboriginal Names; 'Boodjamooling' and 'Boodjameelup'," he said.

"So you don't have to change the name of Hyde Park, just put a sign up saying: 'This area has been used for tens of thousands of years; the Wadjuk name was "Boodjamooling", or something like that."

\section{MR CORUNNA'S STORY}

Nyoongar elder Albert Corunna is the oldest surviving great great grandson of Midgegooroo who at the time of Perth's colonisation was a highly prominent Nyoongar leader.

In 1833, Midgegooroo became the only person ever executed by firing squad in Australia, after being accused but never tried of a leading role in the killing of two colonists near Bull Creek, now a southern suburb of metropolitan Perth. 
Midgegooroo now has a bridge in eastern Perth, a street in Ellenbrook, an avenue in Cockburn Central, and a national park in the Perth Hills named after him.

"I am one of the people who can speak for the Country where Weld Square is," Corunna said.

"The first time I heard of the Coolbaroo Club was when I was about 13 and my cousins went to the dance.

"This was when Coolbaroo was in East Perth and my cousins caught the bus from Bassendean."

Corunna still has a photo of his parents at the Coolbaroo Club at East Perth in 1948.

"Before the club started at Braille Hall on the corner of Stirling and Newcastle Streets there was a meeting at Eden Hill," he said.

"I went to hear the old people talk when I was a teenager.

"I went to the first dance when the Coolbaroo Club re-opened in 1952."

Corunna said his brother and he caught the bus from Sixth Avenue in Bassendean, which is now called Lord Street.

"We had no idea where we were going, but Barney Parfitt was on the same bus and he showed us where to get off," Corunna said.

"At the dance there was a piano player and [Coolbaroo Club leader] Ronnie Kickett was on the drums.

"It was old time dances and the hall was pretty full, mostly Nyoongar people from Eden Hill and East Perth."

Corunna said the dance started about 8pm and finished about 11.30.

"My brother and I caught the bus back to Bassendean and walked through the sand to Lottie Grange's place on what is now called Mary Crescent," he said.

Corunna recounted how on another night when he was about 17 and his brother about 19 they went into town to the pictures.

"At that time it was illegal for Aboriginal people to cross Newcastle Street without a pass," he said.

"I suppose we could have been arrested if the police had stopped us.

"That night we missed the bus home so we slept the night in Weld Square.

"We probably slept there because it was just outside the racial Prohibited Area."

Corunna said lots of Nyoongar people still slept in Weld Square when they had nowhere else to go.

"It is still a meeting place for Aboriginal people," he said.

"My suggestion is that Weld Square be named after the Coolbaroo League to remember those times when it was against the law for Blackfella to be in Perth after 6.00pm.

"When we came to dance right on the edge of the Prohibited Area, we made a political statement as well as having a good time."

Curtin University academic Ted Wilkes, himself a Nyoongar elder descended from Midgegooroo, said that Corunna was a boss, or birdiya, elder.

Associate Professor Wilkes said that if "Uncle Albert" suggested the park be 
named after the Coolbaroo League, then that was good enough for him.

"That's where a lot of our social and cultural activities were generated from, that area," he added.

\section{LOCAL BUSINESS SUPPORT}

Yen Tran, who co-owns the nearby Northbridge Pharmacy, said the plan to give Weld Square an Aboriginal name was a "great idea".

"... it would be a good representation of what the park has meant to our Indigenous people," Tran said.

"And it would be really lovely to carry that on and let other people know that it is there for a reason, because, obviously, we have all of the buildings around us and you know that is the only original piece of land that is still kept as it is."

Sam Rogers who owns Northbridge Dental, located not far from the park, was aware Weld Square had long been a meeting place for Aboriginal people.

“... and Weld, I don't know who Weld is," Rogers said.

"I think he was a governor or something ..."

\section{'BEAUFORT SQUARE'}

Nyoongar woman Lynette Todd-Brophy, who was at the park when we dropped by, said she had always known it as 'Beaufort Park', not Weld Square.

Todd-Brophy said the Beaufort to whom she referred was Robert Beaufort Dinah (1898-1962), a boxer and Nyoongar leader. We can confirm this is not the same "Beaufort"-Irish explorer and inventor Sir Francis Beaufort-from whom adjacent Beaufort Street took its name.

Another Nyoongar woman we spoke to at Weld Square, Pamela Morrison, said she would support an Aboriginal name for the park.

"And I didn't even know it was called 'Weld Square', which means really noth-

ing ...," said Morrison whose views are featured in the following video alongside the opinions of other park-goers.

If a co-name were approved for the park, it would be the latest in a string of co-names around Australia, the best known one being Ayers Rock/Uluru which was co-badged in 1993. Most people now know the rock only by its traditional name of Uluru.

In recent years, many Perth places have been co-badged with a Nyoongar name, or given a Nyoongar name outright. The most prominent example is the mooted Yagan Square, to be named after the legendary Nyoongar freedom fighter, at the emerging Perth City Link project.

Yagan was Midgegooroo's son.

South-western Australia, including Perth, has the highest proportion of Indigenous place names of anywhere in Australia-with more than 50 percent being of Nyoongar origin.

The City of Vincent plans to celebrate NAIDOC Week on Saturday, July 9 at Weld Square from 12.30pm.

The celebration will recognise local Indigenous history, particularly the role of the Coolbaroo League. 
"In recognition of the historical and cultural importance of Weld Square to our local Indigenous community, the NAIDOC Week event also includes the unveiling of a new public artwork by WA artists Sandra Hill and Jenny Dawson, which commemorates and will include personal stories about the Coolbaroo League," Kosova said.

"This artwork was commissioned through major contributions from the City of Vincent and the Metropolitan Redevelopment Authority."

\section{Notes}

1. The spelling of 'Nyoongar' used in this story and in the above exegesis is the spelling that Corunna prefers except where we have quoted an alternative spelling from something that someone else has written.

2. While we recognise that Australia was colonised and there is no reversing the dispossession and other profound effects that came with that colonisation, we use the term 'decolonisation' here in a way similar to that used by Sweet et al. (2014, p. 626), as 'mitigating the effects of colonisation' rather than perpetuating them through, in this case, journalistic practice and production.

\section{References}

Bacon, W. (2006). Journalism as research? Australian Journalism Review, 28(2), 147-157. Bell, D. (2012, February 18). Park's new name a talking point. Perth Voice, p. 5.

Bell, D. (2013, July 20). Name droppers. Perth Voice, p. 6.

Bennell v Western Australia. (2006, September, 19). Federal Court of Australia 1243. Retrieved on November 21, 2016, from www.austlii.edu.au/cgi-bin/sinodisp/au/cases/ cth/FCA/2006/1243.html?stem $=0$ \&synonyms $=0$ \&query $=$ title $($ bennell\%20)

Berg, L. \& Kearns, R. (1996). Naming as norming: 'Race', gender and the identity politics of naming places in Aotearoa/New Zealand. Environment and Planning D: Society and Space, 14(1), 99-122.

Bourdieu, P. (1989). Social space and symbolic power. Sociological Theory, 7(1), 14-25. Bourdieu, P. (1993). The field of cultural production: Essays on art and literature. Cambridge: Polity Press.

Bourdieu, P. (1996/1992). The rules of art: Genesis and structure of the literary field. Stanford: Stanford University Press.

Bourdieu, P. (2001). Television. European Review, 9(3), 245-256.

Buchanan, C. M. (2009). A changing sense of place in Canadian daily newspapers: 18942005. Unpublished doctoral thesis, M.J. Carleton University. Ottawa: Ont., Canada.

Calhoun, C. \& Wacquant, L. (2002). 'Everything is social': In memoriam,. Pierre Bourdieu (1930-2002). Footnotes, 30(2).

City of Vincent (2013). Heritage Assessment, Weld Square. Retrieved on November 21, 2016 from www.vincent.wa.gov.au/agenda/2013/20130723/att/mhi006.pdf

Collard, L., Goodchild, B. \& Marinova, D. (2011). Understanding place names in Southwest Australia. State of Australian Cities Conference, Nov 29-Dec 22011. Melbourne, Vic.: Australian City and Regional Network.

Cohen, S. \& Kliot, N. (1992). Place-names in Israel's ideological struggle over the admi- 
nistered territories. Annals of the Association of American Geographers. 82(4), 653-680.

Creativespirits.info Coolbaroo Club Perth. Retrieved on November 21, 2016, from www. creativespirits.info/australia/western-australia/perth/coolbaroo-club-perth

Ericson, R. V., Baranek, P. M. \& Chan, J. B. (1989). Negotiating control: A study of news sources. Milton Keynes, UK: Open University Press.

Foley, C.A. (1996). The Australian flag: Colonial relic or contemporary icon? Leichhardt, NSW: The Federation Press.

Forrest, S. (2014, April 14). Statement made to students and academic staff, and recorded by Chris Thomson, during ACE project field trip to site of Pinjarra attack.

Funk, M. (2012). Imagined commodities? Analyzing local identity and place in American community newspaper website banners. New Media \& Society, 15(4), 574-595.

Go, J. (2013). Decolonizing Bourdieu: Colonial and postcolonial theory in Pierre Bourdieu's early work. Sociological Theory, 31(1), 49-74.

Hall, S., Critcher, C., Jefferson, T., Clarke, J., \& Roberts, B. (1978). Policing the crisis: Mugging, the state, and law and order. London: MacMillan.

Herman, R. (1999). The aloha state: Place names and the anti-conquest of Hawai'i. Annals of the Association of American Geographers, 89(1), 76-102.

Holmes, K. \& Thomson, C. (2012, December 19) Nyungar leaders pan royal names. Retrieved on November 21, 2016, from www.oneperth.com.au/2012/12/19/nyungarplace-names-elizabeth-quay/

Johnston, M., Bennett, D., Mason, B., \& Thomson, C. (2015a). Finding common ground: combining participatory action research and critical service-learning to guide and manage projects with Aboriginal communities. In B. Bartleet, D. Bennett, A. Power \& N. Sunderland (Eds.), Engaging first peoples in arts-based service learning: towards respectful and mutually beneficial educational practices, pp. 51-70. New York: Springer.

Johnston, M., Bennett, D., Mason, B., \& Thomson, C. (2015b). Service learning in an urban Aboriginal community: "Real Aborigines don't just live in the bush". In B. Bartleet, D. Bennett, A. Power \& N. Sunderland (Eds.), Engaging first peoples in arts-based service learning: towards respectful and mutually beneficial educational practices, (193-210) New York: Springer.

Johnston, M., \& Bishop, R. (2013). Noongar Dandjoo: A work integrated learning case study. Asia Pacific Media Educator, 22(2), 165-177.

Leggett, A. (2015). What's in a name? Retrieved on November 21, 2016, from https:// inkwirenews.com.au/2015/06/09/whats-in-a-name/

Mason, B. (2014). Journalism practice and critical reflexivity: A death in custody interview. Pacific Journalism Review, 20(1), 158-179.

Mason, B., Thomson, C., Bennett, D., \& Johnston, M. (2016). Putting the 'love back in' to journalism: Transforming habitus in Aboriginal affairs student reporting. Journal of Alternative and Community Media, 1(1), 56-69.

Pearce, R., \& Barbetti, M. (1981). A 38,000 year old site at Upper Swan, Western Australia. Archaeology in Oceania, 16, 173-178.

Project for public spaces. (n.d.). What is placemaking? Retrieved on November 21, 2016, from www.pps.org/reference/what is placemaking/

Plumwood, V. (2005). Belonging, naming and decolonisation. In Hillier, J. \& Rooksby, E. (Eds.), Habitus: A sense of place. (2nd ed.: 371-391). Aldershot, England: Ashgate Publishing.

Rapoport, A. (1972). Australian Aborigines and the definition of place. Nature and Human nature, 10. Deakin University. 
Royal Commission into Aboriginal Deaths in Custody. (1991a). Accommodating difference: Relations between Aboriginal and non-Aboriginal people. Retrieved on November 21, 2016, from www.austlii.edu.au/au/other/IndigLRes/rciadic/national/ vol5/5.html\#Heading 11

Royal Commission into Aboriginal Deaths in Custody. (1991b). National report volume 2-12.6 Media. Retrieved on November 21, 2016, from www.austlii.edu.au/au/other/ IndigLRes/rciadic/national/vol2/83.html

Saparov, A. (2003). The alteration of place names and construction of national identity in Soviet Armenia. Cahiers du Monde russe, 44(1), 179-198.

Sawyer, C. (1998). The black stump. Architecture Australia. 87(1). Retrieved on November 21, 2016, from http://architectureau.com/articles/the-black-stump/

skyscrapercity.com (2012). Comments retrieved on November 21, 2016, from http:// www.skyscrapercity.com/showthread.php?t=896896\&page $=355$

South West Aboriginal Land and Sea Council. (n.d.). Prohibited Area Map. Kartdijin Noongar-Noongar Knowledge. Retrieved on November 21, 2016, from http://www. noongarculture.org.au/prohibited-area-map/

South West Aboriginal Land and Sea Council, Host, J. \& Owen, C. (2009). 'It's still in my heart, this is my country': The Single Noongar Claim History. Crawley, WA: UWA Publishing.

Spencer, S. (2005). Contested homelands: Darwin's ‘itinerant problem'. Pacific Journalism Review, 11(1), 174-197.

Stasiuk, G. (2015). Wadjemup: Rottnest Island as black prison and white playground. Unpublished doctoral exegesis Murdoch University, Perth, Western Australia.

Swartz, D. (1997). Culture and power: The sociology of Pierre Bourdieu. Chicago: The University of Chicago Press.

Sweet, M., Dudgeon, P., McCallum, K., \& Ricketson, M. (2014, June). Decolonising practices: Can journalism learn from health care to improve Indigenous health outcomes? Medical Journal of Australia, 11, 626-627.

Thomson, C. (2011, January 2). New Noongar name for Weld Square. Retrieved on November 21, 2016, from www.oneperth.com.au/2011/01/02/nyoongar-name-changefor-weld-square/

Thomson, C. (2012, February 9). Welcome to Wongi Park (Weld Square). Retrieved on November 21, 2016, from www.oneperth.com.au/2012/02/09/welcome-to-wongipark-weld-square/

Thomson, C. (2014, September 27). Noongar name for Perth's newest beach. Retrieved on November 21, 2016, from www.oneperth.com.au/2014/09/27/ngarkal-beach-portcoogee/

Thomson, C., Bennett, D., Johnston, M. \& Mason, B. (2015). Why the where matters: A sense of place imperative for teaching better Indigenous affairs reporting. Pacific Journalism Review, 21(2), 141-161.

Thomson, C., Mason, B., Bennett, D. \& Johnston, M. (2016). Closing the arm's-length gap: Critical reflexivity in student Indigenous affairs journalism. Australian Journalism Review, 38(1), 43-55.

University of Western Australia (2014). Anna Haebich: The Coolbaroo League. Retrieved on November 21, 2016, from www.lwgallery.uwa.edu.au/publicprogram/2014events/2014-08-08 annahaebich

Wacquant, L. (1989). Towards a reflexive sociology: A workshop with Pierre Bourdieu. Sociological theory, 7(1), 26-63. 
www.nzflag.com. It's time to change our flag. Retrieved on November 21, 2016, from www.nzflag.com/itstime.cfm

Zelizer, B. (1995). Reading the past against the grain: The shape of memory studies. Critical Studies in Mass Communication, 12(2), 214-39.

Zelizer, B. (2008). Why memory's work on journalism does not reflect journalism's work on memory. Memory studies, 1(1), 79-87.

Chris Thomson is a journalism lecturer at Curtin University. He was a foundation reporter with Fairfax's Watoday.com.au news website, and before that a reporter for an independent Perth newspaper group. Way back, he was a bilateral trade negotiator and policy and programme manager with the Australian government and then a national industry association. Chris has postgraduate degrees in urban planning, creative writing, and journalism.

chris.thomson@curtin.edu.au

Dr Bonita Mason is a writer, award-winning freelance journalist and journalism lecturer at Curtin University, where she teaches first-year journalism, and feature writing. Her PhD project critiqued mainstream media coverage of Aboriginal deaths in custody, and advocated reflective journalism practice and reflexivity in journalism research. Bonita has also worked as a policy adviser and speechwriter for government, and as a media and policy adviser for Aboriginal land rights and other organisations in the Kimberley region of Western Australia and nationally. bonita.mason@curtin.edu.au 